\title{
HUBUNGAN SOCIAL COMPARISON DAN BODY DISSATISFACTION PADA WANITA YANG MEMILIKI KELEBIHAN BERAT BADAN (OVERWEIGHT)
}

\author{
Aina Nur Alifa dan Gumi Langerya Rizal \\ Jurusan Psikologi, Universitas Negeri Padang, Sumatera Barat \\ Email: aina.nur.alifa@gmail.com,gumi.langerya@gmail.com
}

\begin{abstract}
Abstrak
Rasa tidak puas pada tubuh kerap dirasakan oleh sebagian besar wanita yang memili kelebihan berat badan (overweight). Ketidakpuasan tubuh (body dissatisfaction) tersebut kemungkinan dapat muncul karena tindakan membandingkan diri (social comparison) dengan objek yang dianggap sebagai standar kecantikan. Oleh karena itu, penelitian ini dilakukan yaitu untuk mengetahui apakah ada hubungan antara perbandingan sosial dan ketidakpuasan tubuh pada wanita yang kelebihan berat badan. Metode penelitian yang dilakukan adalah metode kuantitatif koreasional. Teknik sampling yang digunakan adalah teknik purposive sampling, dengan sampel sebanyak 101 wanita kelebihan berat badan yang ada di Provinsi Bengkulu. Data pada penelitian ini dianalisis menggunakan analisis produk momen pearson. Berdasarkan analisis produk momen pearson, ditemukan nilai $r=0,865$ dan nilai $\mathrm{P}=0,00(\mathrm{p}<0,05)$. Hal tersebut menunjukkan jika terdapat hubungan antara perbandingan sosial dan ketidakpuasan tubuh pada wanita yang kelebihan berat badan.
\end{abstract}

Kata kunci : perbandingan sosial, ketidakpuasan tubuh, wanita overweight

SOCIAL COMPARISON AND BODY DISSATISFACTION RELATIONSHIP AMONG OVERWEIGHT WOMEN

\begin{abstract}
Dissatisfaction with the body is often accepted by most women who are overweight. This body dissatisfaction can arise due to the comparison of self (social comparison) with objects that are considered as a standard of beauty. Therefore, this study was conducted to find out whether there is a relationship between social thought and body dissatisfaction in overweight women. The research method used is quantitative quantitative method. The sampling technique used was purposive sampling technique, with a sample of 101 overweight women in Bengkulu Province. Data in this study were analyzed using Pearson moment product analysis. Based on Pearson moment product analysis, the value of $r=0.865$ was found and the value of $P=0.00 \quad(p<0.05)$. This indicate that social comparison and body dissatisfaction had relation in overweight women.
\end{abstract}

Keywords: social dressing, body dissatisfaction, overweight women

\section{Pendahuluan}

Penampilan adalah salah satu hal yang dianggap penting bagi sebagian besar manusia. Saat pertama kali bertemu dengan orang baru, kebanyakan orang akan menilai penampilannya terlebih dahulu barulah kemudian mengenalnya secara personal. Selain itu, penampilan juga dianggap penting karena menjadi salah satu faktor yang mempengaruhi konsep diri seseorang, yaitu hal yang membantu seseorang mengenal dan menilai dirinya sendiri (Saraswatia, Zulpahiyana, \& Arifah, 2016). Pentingnya penampilan membuat seseorang rela melakukan bedah plastik estetik pada bagian tubuhnya yang tidak memuaskan (Gunawan \& Anwar, 2012). Selain melakukan bedah plastik estetik, seseorang dapat menjaga penampilannya agar selalu maksimal dengan menjaga kesehatan dan kebersihan kulit, tata rambut atau kerudung (bagi yang berhijab), dan berat badan yang ideal. Sulitnya mengontrol berat badan ideal menyebabkan banyak wanita mengalami kelebihan berat badan. 
Kelebihan berat badan dikenal juga sebagai kegemukan atau overweight. Dikutip dari laman Depkes.go.id (2015) kegemukan atau kelebihan berat badan (overweight) adalah apabila body mass index (BMI) atau indeks masa tubuh yang diperoleh dari hasil bagi antara berat badan ( $\mathrm{Kg}$ ) dengan tinggi badan yang dinyatakan dalam satuan meter kuadrat $\left(\mathrm{m}^{2}\right)$ berada pada angka lebih dari 23 $\mathrm{kg} / \mathrm{m}^{2}$ hingga $27 \mathrm{~kg} / \mathrm{m}^{2}$, dan dinyatakan obesitas apabila hasil yang diperoleh lebih dari $28 \mathrm{~kg} / \mathrm{m}^{2}$. Selanjutnya dikutip dari hasil Riskesdas (2018) angka kegemukan pada usia dewasa ( $>18$ tahun) di Indonesia terus meningkat tiap tahunnya, pada tahun 2018 meningkat hingga 21,8\%. Berdasarkan proporsi kegemukan pada dewasa ( $>18$ tahun) menurut provinsi pada tahun 2018, Provinsi Bengkulu mencatat angka kegemukan sebanyak lebih kurang $20 \%$.

Dalam beberapa kasus, kegemukan dapat ditanggapi positif oleh sebagian wanita overweight. Beberapa wanita dengan kelebihan berat badan dapat dengan percaya diri menunjukkan dirinya sebagai model plus size (Nadiva, 2018) ataupun instagram's influencer (Anjani, 2016). Tetapi tidak sedikit kegemukan ditanggapi negatif bagi sebagian wanita seperti diantaranya kasus diet ekstrim yang dilakukan oleh Melody yang membuat dirinya mengalami bulimia dan anoreksia (Putri, 2018). Selain Melody, kasus terkait kegemukan lainnya adalah dua orang remaja di Jakarta yang mengalami osteoporosis akibat diet ekstrim yang mereka lakukan (Sukardi, 2018). Kedua orang remaja yang berusia 18 dan 20 tahun tersebut terobsesi untuk menjadi seperti idola mereka yang dianggap memiliki tubuh super ideal. Demi mendapatkan tubuh ideal keduanya menahan diri untuk tidak makan dalam jangka waktu yang panjang sehingga berujung pada osteoporosis. Peneliti juga melakukan wawancara singkat dengan salah seorang dokter jaga bagian IGD di RSUD.M Yunus, Bengkulu. berdasarkan jawaban dari dokter tersebut dirinya pernah menangani pasien IGD yang mengalami hipokalemi yang menyebabkan pasien tremor dan kehilangan kesadaran, setelah diperiksa lebih lanjut diketahui jika hal tersebut terjadi karena pasien tersebut melakukan diet ekstrim (R.P.Yolanda, komunikasi pribadi, Juni 2020).

Berdasarkan penelitian yang dilakukan oleh Munawarah (2017) kelebihan berat badan menyebabkan wanita mengalami tekanan pada standar kecantikan di lingkungan sosial, mendapatkan julukan yang tidak disukai (seperti ndut, gajah, gembrot, dan gempal), dan dijadikan bahan gurauan. Perlakuan seperti pemberian julukan yang tidak disukai tersebut dapat menimbulkan perasaan rendah diri atau feeling of inferiority yang menyebabkan seseorang menarik diri dari lingkungannya. Selanjutnya berdasarkan penelitian yang dilakukan oleh Meiliana, Valentina, dan Retnaningsih (2018) kegemukan menjadi hal yang membuat seseorang terutama wanita merasa tidak puas terhadap tubuhnya atau body dissatisfaction, maka untuk memperoleh bentuk badan yang menarik adalah alasan $66 \%$ responden dalam penelitiannya melakukan diet.

Ketidakpuasan tubuh atau body dissatisfaction merupakan bentuk penilaian negatif dari citra tubuh, didefinisikan sebagai perbedaan antara ukuran persepsi seseorang dan ukuran ideal yang mereka harapkan (Cash \& Pruzinsky, 2002). Ketidakpuasan tubuh menjadi salah satu hal yang memberikan dampak buruk bagi sebagian orang. Seperti kasus yang disampaikan pada paragraf sebelumnya, dalam sebuah penelitian ditemukan bahwa ketidakpuasan tubuh menjadi faktor internal yang mendorong terjadinya perilaku diet tidak sehat karena persepinya terhadap ketidakpuasan dirinya pada tubuhnya (Abdurrahman, 2014). Diet tidak sehat diantaranya sering terjadi pada kasus anoreksia dan bulimia seperti menahan diri untuk tidak makan dan konsumsi obat pencahar berlebihan. Dampak dari diet tidak sehat tersebut adalah menurunnya tekanan darah, 
melambatnya denyut jantung, timbul masalah pada ginjal dan pencernaan, serta pada beberapa kasus terjadi kerontokan rambut (Davidson, John, \& Ann, 2006).

Menurut Cash, Winstead, dan Janda (dalam Matz, Foster, Faith, \& Wadden, 2002) ketidakpuasan tubuh lebih umum di antara orang yang mengalami kegemukan daripada orang yang tidak kegemukan dan lebih tinggi pada wanita gemuk daripada pria gemuk. Salah satu faktor yang menyebabkan wanita merasa tidak puas dengan tubuhnya adalah ketika wanita membandingkan tubuhnya dengan orang lain yang dianggap menarik (Sunartio, Sukamto, \& Dianovinina, 2012).

Tindakan membandingan diri tersebut dikenal sebagai social comparison atau perbandingan sosial. Teori perbandingan sosial yang dijelaskan oleh Festinger (dalam Myers \& Crowther, 2009), menyebutkan bahwa orang memiliki dorongan untuk menentukan kemajuan dan kedudukan mereka dalam kehidupan. Sebagai akibat dari dorongan untuk menentukan kemajuan yang dimiliki, orang akan cenderung mencari standar yang dapat mereka jadikan objek pembanding. Teori ini membedakan dua jenis perbandingan sosial yaitu perbandingan sosial ke atas dan perbandingan sosial ke bawah. Tindakan yang dilakukan oleh individu berupa membandingkan dirinya dengan seseorang yang dinilai lebih baik dari dirinya disebut sebagai perbandingan keatas (upward comparison). Sebaliknya, ketika individu membandingkan diri mereka dengan seseorang yang dinilai tidak lebih baik dari dirinya disebut sebagai perbandingan sosial kebawah (downward comparison). Bentuk perbandingan sosial diantaranya ditemukan dalam penelitian yang dilakukan oleh Putra, Putra, dan Diny (2019). Dalam penelitiannya, sebagian subjek membandingkan dirinya dengan artis dan temannya yang dianggap memiliki penampilan yang ideal. Proses membandingkan diri tersebut menyebabkan subjek merasa tidak puas dengan tubuhnya. Berdasarkan yang telah dijabarkan, peneliti ingin mengetahui bagaimana tingkat social cmparison dan tingkat body dissatisfation pada wanita yang memiliki kelebihan berat badan. Kemudian peneliti juga ingin mengetahui apakah perbandingan sosial menjadi salah satu hal yang memiliki hubungan terhadap ketidakpuasan tubuh tersebut.

\section{Metode Penelitian}

Metode yang digunakan adalah metode kuantitatif. Metode penelitian kuantitatif dikenal sebagai metode penelitian dengan data berupa angka-angka dan data tersebut dianalisis menggunakan analisis statistik. Berdasarkan hubungan antar variabelnya, penelitian ini termasuk kedalam jenis penelitian yang bersifat interaktif karena melihat hubungan (korelasi) antara kedua variabel, yaitu antara social comparison dan body dissatisfaction (Sugiyono, 2013).

Teknik sampling yang digunakan adalah teknik purposive sampling. Sampling purposive dipilih karena teknik ini menenentukan sampel dengan melakukan pertimbangan tertentu (Sugiyono, 2013). Kriteria sampling diantaranya adalah wanita yang berusia 21 hingga 40 tahun, berasal dari Provinsi Bengkulu, memiliki kelebihan berat badan dengan indeks masa tubuh (BMI) $23-27 \mathrm{~kg} / \mathrm{m}^{2}$. Pengumpulan data dilakukan dengan menyebar google form keseluruh kabupaten/kota Provinsi Bengkulu melalui media sosial. Data yang terkumpul kemudian dilakukan uji normalitas, linearitas, kemudian dianalisis menggunakan uji korelasi product moment.

\section{Subjek Penelitian}

Subjek pada penelitian adalah 101 wanita yang sesuai dengan kriteria penelitian yaitu berusia 2140 tahun, memiliki BMI $23 \mathrm{Kg} / \mathrm{m}^{2}$ hingga $27 \mathrm{Kg} / \mathrm{m}^{2} .101$ wanita tersebut tersebar di 10 kabupaten dan kota yang terdapat dibengkulu diantaranya, Kota Bengkulu, Kabupaten Seluma, Kabupaten Bengkulu 
Selatan, Kabupaten Bengkulu Tengah, Kabupaten Bengkulu Utara, Kabupaten Lebong, Kabupaten Rejang Lebong, Kabupaten Kepahiang, Kabupaten Kaur, Dan Kabupaten Muko-Muko.

\section{Variabel dan Instrumen Penelitian}

Terdapat dua variabel dalam penelitian ini, yaitu social comparison sebagai variabel $\mathrm{X}$ atau variabel bebas dan body dissatisfaction sebagai variabel $\mathrm{Y}$ atau variabel terikat.

Definisi operasional untuk body dissatisfaction adalah adalah total skor jawaban responden terhadap skala ketidakpuasan tubuh (MBSRQ-AS) yang disusun oleh Swami et al. (2019) berdasarkan aspek-aspek ketidakpuasan tubuh yang terdiri atas, orientasi penampilan, evaluasi penampilan, perhatian terhadap kelebihan berat badan, klasifikasi berat badan, dan kepuasan pada bagian tubuh tertentu.

Definisi operasional untuk social comparison adalah total skor jawaban responden terhadap skala perbandingan sosial (PACS-R) berdasarkan aspek-aspek perbandingan sosial yang terdiri atas, physical appearance (penampilan fisik), weight (berat tubuh), body shape (bentuk tubuh), body size (ukuran tubuh), dan body fat (lemak tubuh)(Schaefer \& Thompson, 2014).

Skala yang digunakan adalah skala likert dengan rentang skor jawaban 1 sampai 5 (sangat tidak sesuai-sangat sesuai) untuk item favourable dan rentang skor jawaban 5 sampai 1 (sangat tidak sesuai-sangat sesuai) untuk item unfavourable. Sebelum dilakukan penelitian, terlebih dahulu peneliti melakukan uji coba terhadap 34 item body dissatisfaction dan 11 item social comparison untuk mengetahui reliabilitas dan validitasnya dan uji coba dilakukan kepada 82 orang wanita. Suatu item dikatakan valid apabila nilai $r$ tabel $>r$ hitung dengan $d f=82-2=80$ dengan nilai $r$ tabel= 0,220 . Setelah dilakukan pengolahan pada data hasil uji coba, ditemukan hasil sebagai berikut.

Tabel 1. Properti Psikometris Alat Ukur

\begin{tabular}{cccc}
\hline Alat ukur & Jumlah item & Validitas & reliabilitas \\
\hline MBSRQ-AS & 22 & $0,224-0,612$ & 0,794 \\
PACS-R & 11 & $0,726-0,900$ & 0,963 \\
\hline
\end{tabular}

\section{Prosedur dan Analisis Data}

Terdapat tiga tahapan yang dilakukan pada penelitian ini. Tahap pertama adalah persiapan, peneliti mencari dan mengumpulkan fenomena yang terkait dengan tema. Berdasarkan fenomena yang telah dikumpulkan dan disusun, selanjutnya peneliti menentukan rumusan masalah yang tepat. Selain fenomena dan rumusan masalah, peneliti juga menentukan populasi serta teknik yang digunakan untuk mendapatkan sampel. Bagian terakhir pada tahap ini, peneliti mempersiapkan alat ukur yang tepat untuk mengukur kedua variabel.

Tahapan yang kedua adalah pelaksanaan, alat ukur yang telah dipersiapkan selanjutnya diserahkan pada dua orang dosen Jurusan Psikologi Universitas Negeri Padang untuk dilakukan proffessional judgement. Setelah mendapat persetujuan dari dosen, selanjutnya alat ukur diujicobakan untuk mengetahui validitas dan reliabilitasnya menggunakan cronbach's alphadan analisisis faktor KMO dengan bantuan program SPSS for windows. Data yang dikumpulkan dari uji coba selanjutnya dianalisis untuk mengetahui item-item apa saja yang gugur sehingga alat ukur dapat disusun kembali. Alat ukur yang sudah sesuai kemudian digunakan dalam penelitian untuk menjawab rumusan masalah pada penelitian. 
Tahapan terakhir yaitu analisis data, terdapat tiga langkah dalam melakukan analisis pada penelitian ini setelah data yang dibutuhkan telah terkumpul pada proses pengumpulan data sebelumnya. Pertama, data yang telah di skoring diuji sebaran datanya apakah normal atau tidak normal. Kedua, data dianalisis linearitasnya untuk melihat apakah kedua variabel memiliki hubungan yang linear. Tahap terakhir adalah menguji korelasi variabel menggunakan product moment pearson dengan bantuan program SPSS for windows.

\section{Hasil Penelitian}

Penelitian dilakukan dengan menyebarkan link google form melalui media sosial agar dapat menjangkau subjek dari sepuluh kabupaten dan kota di Provinsi Bengkulu. Dari seluruh data yang terkumpul, total 101 wanita yang memenuhi kriteria subjek akhirnya dianalisis. Berikut deskripsi subjek secara umum.

Tabel 2. Deskripsi subjek berdasarkan daerah

\begin{tabular}{lccc}
\hline No & Asal & N & Persentase (\%) \\
\hline 1. & Kota Bengkulu & 66 & $65,35 \%$ \\
2. & Kabupaten Bengkulu Selatan & 3 & $2,97 \%$ \\
3. & Kabupaten Bengkulu Utara & 6 & $5,94 \%$ \\
4. & Kabupaten Bengkulu Tengah & 7 & $6,93 \%$ \\
5. & Kabupaten Rejang Lebong & 4 & $3,96 \%$ \\
6. & Kabupaten Lebong & 2 & $1,98 \%$ \\
7. & Kabupaten Seluma & 6 & $5,94 \%$ \\
8. & Kabupaten Kaur & 4 & $3,96 \%$ \\
9. & Kabupaten Kepahiang & 2 & $1,98 \%$ \\
10. & Kabupaten Muko-muko & 1 & $0,99 \%$ \\
\hline & Total & 101 & $100 \%$ \\
\hline
\end{tabular}

Berdasarkan tabel diatas, diketahui bila responden terbanyak berasal dari Kota Bengkulu dengan total responden sebanyak 66 orang $(65,35 \%)$. Responden yang berasal dari Kabupaten Bengkulu Selatan sebanyak 3 orang (2,97\%), Kabupaten Lebong dan Kabupaten Kepahiang masing-masing sebanyak 2 orang (1,98\%), Kabupaten Rejang Lebong dan Kabupaten Kaur masing-masing sebanyak 4 orang (3,96\%), Kabupaten Bengkulu Tengah sebanyak 7 orang (6,93\%), Kabupaten Bengkulu Utara dan Kabupaten Seluma masing-masing sebanyak 6 orang $(5,94 \%)$. Responden paling sedikit yaitu sebanyak 1 orang (0,99\%) berasal dari Kabupaten Muko-muko. 
Tabel 3. Tingkat body dissatisfaction dan social comparison pada wanita overweight

\begin{tabular}{ccccc}
\hline Kategori & \multicolumn{2}{c}{ Body dissatisfaction } & \multicolumn{2}{c}{ Social comparison } \\
\cline { 2 - 5 } Sangat rendah & Frekuensi & Persentase (\%) & Frekuensi & Persentase (\%) \\
Rendah & 5 & $4,95 \%$ & 9 & $8,91 \%$ \\
Sedang & 21 & $20,79 \%$ & 16 & $15,84 \%$ \\
Tinggi & 35 & $34,65 \%$ & 32 & $31,68 \%$ \\
Sangat tinggi & 32 & $31,68 \%$ & 30 & $29,70 \%$ \\
Total & 8 & $7,92 \%$ & 14 & $13,86 \%$ \\
\hline
\end{tabular}

Berdasarkan tabel diatas diketahu jika responden yang memiliki body dissatisfaction dalam kategori sangat rendah sebanyak 4,95\% (5 orang) hal ini menunjukkan jika hanya sedikit wanita overweight dengan ketidakpuasan tubuh yang rendah, kategori rendah sebanyak 20,79\% (21 orang), kategori sedang sebanyak 34,65\% (35 orang) hal ini menunjukkan jika kebanyakan wanita overweight dengan ketikpuasan tubuh yang sedang, kategori tinggi cukup banyak yaitu 31,68\% (32 orang) dan kategori sangat tinggi sebanyak $7,92 \%$ (8 orang). Artinya sebagian besar wanita overweight merasakan ketidakpuasan tubuh yang sedang, sebagian besar lainnya dalam kategori tinggi dan sebagian lainnya sangat tinggi, rendah dan sangat rendah. Pada variabel social comparison responden dalam kategori sangat rendah paling sedikit yaitu sebanyak 8,91\% (9 orang), kategori rendah sebanyak $15,84 \%$ (16 orang), dalam kategori sedang memiliki responden paling banyak yaitu sebanyak 31,68\% (32 orang), kategori tinggi sebanyak 29,70\% (30 orang), dan kategori sangat tinggi sebanyak 13,86\% (114 orang). Sama seperti body dissatisfaction sebagian besar wanita overweight melakukan perbandingan sosial dalam kategori sedang, sebagian besar lainnya dalam kategori tinggi, dan sebagian lainnya dalam kategori sangat tinggi, rendah, dan sangat rendah.

Pada uji normalitas ditemukan hasil berupa nilai (P) untuk skala body dissatisfaction adalah 0,200 $(P>0,05)$ dan nilai $(P)$ untuk skala social comparison adalah 0,063 $(P>0,05)$. Berdasarkan temuan tersebut, maka kedua skala dinyatakan berdistribusi normal. Selanjutnya pada uji linearitas ditemukan diketahui jika nilai $P$ untuk linearity adalah $0,000(<0,05)$ dan nilai $F 442,475$. Hal tersebut menunjukkan jika hubungan kedua variabel linear. Setelah dilakukan uji normalitas dan linearitas, berikut adalah hasil untuk uji korelasi yang dilakukan:

Tabel 4. Hasil Analisis

\begin{tabular}{cc}
\hline Ketentuan & Nilai \\
\hline Koefisien korelasi & 0,865 \\
Kontribusi X terhadap Y & 0,748 \\
Korelasi (P) & 0,000 \\
Keterangan & signifikan \\
\hline
\end{tabular}

Berdasarkan tabel diatas, diketahui jika nilai korelasi antara Y (body dissatisfaction) dan X (social comparison) adalah 0,865 . Nilai tersebut menunjukkan jika kedua variabel memiliki hubungan yang kuat (Syahrum dan Salim, 2012). Kolom sig pada tabel menunjukkan nilai $P$, sehingga diperoleh nilai $P$ sebesar 0,000 . Nilai $P<0,05$ menunjukkan jika Hipotesis diterima. Koefisien korelasi yang bernilai positif menunjukkan jika hubungan antara kedua variabel adalah positif. Kontribusi variabel $x$ terhadap y dapat dilihat pada tabel model summary pada kolom R Square yaitu 0.748 artinya social comparison menjadi $74,8 \%$ faktor yang dapat memunculkan body dissatisfaction. 


\section{Pembahasan}

Tujuan dalam penelitian yang dilakukan adalah untuk menemukan apakah social comparison $(X)$ dan body dissatisfaction( $Y$ ) pada wanita yang memiliki kelebihan berat badan atau overweight memiliki hubungan. Penelitian ini didasarkan atas temuan dilapangan yang menunjukkan jika angka kegemukan hingga obesitas terus meningkat di Indonesia khususnya di Provinsi Bengkulu. Untuk mengetahui jawaban apakah terdapat hubungan antara kedua variabel tersebut, peneliti selanjutnya melakukan penelitian kepada 101 wanita yang memiliki kelebihan berat badan dengan kisaran BMI $23-28 \mathrm{~kg} / \mathrm{m}^{2}$ dengan rentang usia 21-40 tahun yang tersebar disepuluh kabupaten dan kota di Provinsi Bengkulu.

Setelah serangkaian penelitian dilakukan, berdasarkan hasil analisis data menggunakan teknik analisis product moment dengan bantuan SPSS for Windows versi 23 ditemukan nilai P sebesar 0,000 dan nilai koefisien korelasi yang bernilai positif sebesar 0,865 . Nilai $P$ yang lebih kecil dari 0,05 menunjukkan jika hipotesis diterima, yaitu antara social comparison dan body dissatisfaction pada wanita overweight terdapat hubungan yang signifikan. Koefisien korelasi yang ditemukan juga menunjukkan jika hubungan antara social comparison dan body dissatisfaction sangat kuat. Nilai koefisien yang positif menunjukkan hubungan antara kedua variabel yang positif yaitu semakin tinggi social comparison yang dilakukan oleh wanita kegemukan, semakin tinggi juga ketidakpuasan pada tubuhnya dan begitu pula sebaliknya. Analisis regresi ditambahkan untuk mengetahui seberapa besar kontribusi social comparison terhadap body dissatisfaction pada wanita yang memiliki kelebihan berat badan.

Berdasarkan analisis resgresi, ditemukan jika social comparison menjadi $74,8 \%$ faktor yang mempengaruhi body dissatisfaction dan 25,2\% lainnya merupakan faktor yang tidak diteliti. Hasil tersebut menunjukkan jika social comparison berkontrbusi cukup besar terhadap body dissatisfaction. Sesuai dengan penelitian yang menunjukkan social comparison menjadi salah satu faktor untuk body dissatisfaction yang dilakukan oleh Fuller-Tyszkiewicz et al. (2019). Penelitiannya menjelaskan, diantara beberapa prediktor, perbandingan sosial berdasarkan penampilan menjadi prediktor paling signifikan penyebab munculnya ketidakpusan tubuh yaitu sebesar $60 \%$.

Sesuai dengan temuan pada penelitian sebelumnya yang dilakukan Sunartio et al. (2012) bahwa terdapat hubungan positif antara social comparison dan body dissatisfaction khususnya pada wanita dewasa awal. Hubungan positif antara kedua variabel menunjukkan jika semakin sering wanita melakukan perbandingan penampilan fisiknya dengan orang lain maka akan meningkatkan rasa tidak puas pada tubuhnya.

Penelitian serupa menemukan jika rasa ketidakpuasan terhadap tubuh yang dimiliki yang diakibatkan seringnya seseorang melakukan perbandingan sosial berdasarkan penampilan (Putra et al., 2019). Penelitian tersebut juga menemukan jika responden dengan ketidakpuasan tubuh sangat tinggi kerap merasa jika dirinya ditertawakan dan dijadikan bahan bully dikarenakan penampilannya yang menurutnya tidak sesuai dengan standar kecantikan yang ada disekitarnya.

Penelitian lain menunjukkan gambaran social comparison yang dapat menyebabkan timbulnya tidak puas pada tubuh yang terkhususnya dimiliki oleh wanita. Wanita hamil memiliki kecenderungan untuk mengalami ketidakpuasan tubuh, hal tersebut salah satunya disebabkan oleh perilaku membandingkan penampilannya dengan orang lain (Dryer, Schulenburg, \& Brunton, 2020). Membandingkan penampilan yang dimaksudkan timbul akibat adanya beberapa faktor salah satu diantaranya Fat Talk atau kegiatan membicarakan lemak tubuh atau ukuran tubuh dalam konteks 
yang negatif. Fat Talk kemudian memasukkan unsur membandingkan diri dengan tekanan standar sosiokultural yang dapat berujung pada ketidakpuasan tubuh.

Social comparison dibangun atas lima aspek diantaranya penampilan fisik, berat tubuh, bentuk tubuh, ukuran tubuh dan lemak tubuh. Aspek lemak tubuh yang memiliki skor rata-rata pada data empirik lebih kecil dibandingkan data hipotetiknya menunjukkan jika kebanyakan responden tidak membandingkan lemak tubuh. Hal tersebut mungkin terjadi karena lemak tubuh tidak dapat dilihat kategorinya begitu saja. Lemak tubuh dapat dikategorikan menggunakan penghitungan khusus atau alat pengukur khusus lemak tubuh.

Aspek dengan rentang skor rata-rata pada data empirik dan hipotetik tertinggi adalah aspek penampilan fisik. Hal ini menunjukkan jika dalam melakukan perbandingan sosial, responden cenderung membandingkan bentuk fisik atau penampilan fisiknya terlebih dahulu. Membandingkan penampilan fisik menjadi memungkinkan karena cukup mudah untuk dilihat dan dikategorikan. Temuan ini dikuatkan dengan hasil penelitian sebelumnya terkait membandingkan penampilan fisik yang dilakukan oleh remaja dan wanita dewasa. Dwiputeri dan Maulina (2015) menemukan jika terdapat kontribusi dari membandingkan diri dengan idol k-pop terhadap ketidakpuasan tubuh yang dimiliki oleh remaja. Remaja yang mudah mengakses segala sesuatu tentang $k$-pop terutama melalui media internet turut mempermudah mereka melihat dan mengamati penampilan fisik idol $k$-pop untuk kemudian diinternalisasikan kedalam dirinya. Tidak sesuainya penampilan fisik idol k-pop dengan penampilan yang dimiliki oleh remaja putri dapat menimbulkan ketidakpuasan tubuh dan tidak sedikit berujung pada berusaha mengubah penampilan fisik, salah satunya diet ekstrim.

Dapat dilihat berdasarkan skor yang diperoleh masing-masing responden, menunjukkan jika sebagian besar responden memiliki ketidakpuasan tubuh yang berada pada kategori sedang, sebagian besar lainnya memiliki ketidakpuasan tubuh yang tinggi. Hanya sedikit responden yang memiliki ketidakpuasan tubuh pada kategori rendah demikian pula dengan perbandingan sosialnya

\section{Kesimpulan}

Berdasarkan penelitian yang telah dilakukan, berikut adalah beberapa yang dapat disimpulkan;

1. Berdasarkan temuan pada penelitian ini, sebagian besar wanita overweight memiliki tingkat body dissatisfaction yang sedang, namun tidak sedikit wanita yang meiliki ketidakpuasan tubuh pada kategori tinggi dan sangat tinggi.

2. Serupa dengan body dissatisfaction, sebagian besar wanita overweight memiliki tingkat social comparison sedang, namun tidak sedikit wanita yang meiliki ketidakpuasan tubuh pada kategori tinggi dan sangat tinggi.

3. Terdapat hubungan antara social comparison dan body dissatisfaction pada wanita yang memiliki kelbihan berat badan (overweight). Penelitian ini menunjukkan social comparison dan body dissatisfaction memiliki arah hubungan yang positif. Hubungan positif tersebut menunjukkan jika semakin tinggi perbandingan sosial yang dilakukan oleh seseorang maka semakin tinggi pula ketidakpuasan tubuh yang dimilikinya dan sebaliknya semakin rendah perbandingan sosial yang dilakukan oleh seseorang maka semakin rendah pula ketidakpuasan tubuh yang dimilikinya. Social comparison menjadi $74.8 \%$ faktor yang berkontribusi terhadap body dissatisfaction pada wanita yang memiliki kelebihan berat badan 


\section{Daftar Pustaka}

Abdurrahman, F. (2014). Faktor-faktor pendorong perilaku diet tidak sehat pada wanita usia dewasa awal. EJournal Psikologi, 2(2), 163-170.

Anjani, Rahmi.(2016).7 Selebgram Plus Size Indonesia yang Eksis di Instagram. [Online]. Tersedia: https://wolipop.detik.com/fashion-news/d-3259227/7-selebgram-plus-size-indonesia-yangeksis-di-instagram . Dikutip tanggal 28/01/2020.

Cash, T. F., \& Pruzinsky, T. (2002). Body image: a handbook of theory, research, and clinical practice. In The Guilford Press. https://doi.org/10.1001/jama.289.14.1861

Davidson Gerald.C, John M. Neale, \& Ann M.Kring.2006.Psikologi abnormal:edisi 9.Jakarta: Pt Raja Grafindo Persada.

Depkes RI. (2015) Kamus. [Online]. Tersedia: http://www.depkes.go.id/index.php?txtKeyword=status+gizi\&act=search-bymap\&pgnumber $=0 \&$ charindex $=\&$ strucid $=1280$ \& fullcontent $=1 \& C-A L L=1$. Dikutip tanggal 08-102019.

Dryer, R., Schulenburg, I. G. von der, \& Brunton, R. (2020). Body dissatisfaction and Fat Talk during pregnancy: Predictors of distress. Journal of Affective Disorders, 267, 289-296. https://doi.org/10.1016/j.jad.2020.02.031

Dwiputeri, L., \& Maulina, V. V. R. (2015). Kontribusi body comparison dengan artis k-pop perempuan terhadap body dissatisfaction (studi pada remaja perempuan indonesia fans k-pop). Jurnal Perkotaan, 7(1-2), 58-76. https://doi.org/10.25170/perkotaan.v7i1-2.271

Fuller-Tyszkiewicz, M., Chhouk, J., McCann, L. A., Urbina, G., Vuo, H., Krug, I., ... Richardson, B. (2019). Appearance comparison and other appearance-related influences on body dissatisfaction in everyday life. Body Image, 28, 101-109. https://doi.org/10.1016/j.bodyim.2019.01.002

Gunawan, R., \& Anwar, A. (2012). Kecemasan body image pada perempuan dewasa tengah yang melakukan bedah plastik estetik. Jurnal Psikologi, 10(2), 58-67.

Matz, P. E., Foster, G. D., Faith, M. S., \& Wadden, T. A. (2002). Correlates of body image dissatisfaction among overweight women seeking weight loss. Journal of Consulting and Clinical Psychology, 70(4), 1040-1044. https://doi.org/10.1037/0022-006X.70.4.1040

Meiliana, M., Valentina, V., \& Retnaningsih, C. (2018). Hubungan body dissatisfaction dan perilaku diet pada mahasiswa universitas katolik soegijapranata semarang. Praxis, 1(1), 49-62. https://doi.org/10.24167/PRAXIS.V111.1628

Munawarah R.A., R. R. (2017). Feeling of inferiority siswa obesitas di smpi khaira ummah padang. Marwah: Jurnal Perempuan, Agama Dan Jender, 16(1), 32. https://doi.org/10.24014/marwah.v16i1.3568

Myers, T. A., \& Crowther, J. H. (2009). Social comparison as a predictor of body dissatisfaction: a meta-analytic review. Journal of Abnormal Psychology, 118(4), 683-698. https://doi.org/10.1037/a0016763 
Nadiva, Risda.(2018). Siapa bilang gemuk tidak menarik? 7 model big size ini masih tetap seksi kok.[Online]. Tersedia: https://lifestyle.okezone.com/read/2018/12/27/194/1996782/siapabilang-gemuk-tak-menarik-7-model-big-size-ini-masih-tetap-seksi-kok Dikutip tanggal 22/12/19

Putra, H. N., Putra, A. I. D., \& Diny, A. (2019). Body dissatisfaction ditinjau dari social comparison pada siswi sekolah menengah atas. Journal of Education, Humaniora and Social Sciences (JEHSS), 2(1), 1-11. https://doi.org/10.34007/jehss.v2i1.46

Putri, Wulan Kurnia. (2018). Kerap dibully gara-gara tubuhnya gemuk, cewek ini menderita bulimia \& anoreksia karena inggin kurus. [Online]. Tersedia: https://wow.tribunnews.com/2018/01/17/kerap-dibully-gara-gara-tubuhnya-gemuk-cewek-inimenderita-bulimia-anoreksia-karena-inggin-kurus. dikutip tanggal 05/03/2020.

Saraswatia, G. K., Zulpahiyana, Z., \& Arifah, S. (2016). Faktor-Faktor yang mempengaruhi konsep diri remaja di SMPN 13 yogyakarta. Jurnal Ners Dan Kebidanan Indonesia, 3(1), 33. https://doi.org/10.21927/jnki.2015.3(1).33-38

Schaefer, L. M., \& Thompson, J. K. (2014). The development and validation of the Physical Appearance Comparison Scale-Revised (PACS-R). Eating Behaviors, 15(2), 209-217. https://doi.org/10.1016/j.eatbeh.2014.01.001

Sugiyono.(2013).Metode penelitian kuantitatif kualitatif dan R\&D. Bandung: Alfabeta.

Sukardi, Muhammad. (2018). Gara-gara diet ekstrem, remaja di jakarta alami osteoporosis. [Online]. Tersedia: $\quad$ https://lifestyle.okezone.com/read/2018/10/19/481/1966347/gara-gara-dietekstrem-remaja-di-jakarta-alami-osteoporosis. dikutip Tanggal 05/03/2020.

Sunartio, L., Sukamto, M. E., \& Dianovinina, K. (2012). Social comparison dan body dissatisfaction pada wanita dewasa awal. Humanitas, 9(2), 157-168. https://doi.org/10.26555/humanitas.v9i2.342

Swami, V., Todd, J., Nor, N. A., Toh, E. K. L., Zahari, H. S., \& Barron, D. (2019). Dimensional structure, psychometric properties, and sex invariance of a bahasa malaysia (malay) translation of the multidimensional body-self relations questionnaire-appearance scales (MBSRQ-AS) in malaysian malay adults. Body Image, 28, 81-92. https://doi.org/10.1016/j.bodyim.2018.12.007

Syahrul dan Salim. (2012). Metodologi penelitian kuantitatif. Bandung: Ciptapustaka Media.

Riskesdas. (2018). Hasil utama rikesdas.Badan Penelitian dan Pengembangan. Kementerian Kesehatan.Kesehatan Republik Indonesia. 